Ewa Kula

Uniwersytet Jana Kochanowskiego w Kielcach

Adam Massalski

Wyższa Szkoła Pedagogiczna im. Janusza Korczaka w Warszawie

\title{
ZWIĄZKI KRÓLESTWA POLSKIEGO Z EUROPĄ ZACHODNIĄ W DZIEDZINIE OŚWIATY I NAUKI W ŚWIETLE PROTOKOŁÓW POSIEDZEŃ RWP W LATACH 1845-1850*
}

\author{
Relations between the Polish Kingdom with Western Europe \\ in the field of education and science in the light of protocols
}

from the sittings of the Council of Public Education in the years 1845-1850

The Council of Public Education was created by the law on schooling of July 15, 1833 and was supposed to take over a number of powers that used to belong to the Government Commission on Religions and Public Enlightenment. During years between the insurrections (1831-1863), scientific and education relations of the Polish Kingdom and Western Europe were radically restricted. It was reflected in the protocols of the Council's sittings that included only incidental records of cases of Polish scientists and teachers leaving abroad for scientific purposes. In majority, decisions of the Council having to do with international relations at that time concerned purchases of items and exhibits and, less often, of magazines for scientific institutions, as Botanical Garden, Zoological Hall, or Public Library. Records in the protocols are therefore a proof of limited role of the Council of Public Education in the management of educational system of the Polish Kingdom during that period.

Keywords: Polish Kingdom, Council of Public Education, Warsaw Scientific District, inter-insurrection years, co-operation with abroad

Słowa kluczowe: Królestwo Polskie, Rada Wychowania Publicznego, Warszawski Okręg Naukowy, lata międzypowstaniowe, współpraca z zagranicą.

* Publikacja przygotowana $\mathrm{w}$ ramach grantu NCN: Rada Wychowania Publicznego w Królestwie Polskim w latach 1833-1867. Protokoły posiedzeń (Nr UMO-2011/03/B/ HS3/02039). 
Protokoły posiedzeń Rady Wychowania Publicznego zachowały się w Rosyjskim Państwowym Archiwum Historycznym w Sankt Petersburgu, w zespole Ministerstwa Oświecenia Publicznego, fond 733 - Departament Oświecenia Publicznego. Jest to 16 teczek, zawierających protokoły za lata 1845-18591․ Teczki te są o dość zróżnicowanej objętości, od 38 do 565 kart rękopisów, najczęściej zapisywanych dwustronnie. Dotychczas opracowano i wydano drukiem dokumenty za lata 1845-1850 (z wyjątkiem 1847 r., z którego nie zachowały się protokoły), liczące 2986 stron rękopisu². Z tego powodu cezura przyjęta w artykule obejmuje właśnie lata 18451850. Protokoły z lat 1851-1859 czekają na opracowanie i opublikowanie.

Rada Wychowania Publicznego działała początkowo, w latach 1833-1840 jako „główna zwierzchność szkolna”, na wzór organów kolegialnych funkcjonujących w Imperium. Powołana była ustawą szkolną z 15 lipca 1833 r. i miała przejąć szereg uprawnień, które dawniej należały do Komisji Rządowej Wyznań Religijnych i Oświecenia Publicznego. W skład Rady wchodzili: prezydujący, którym był dyrektor główny Komisji Rządowej Spraw Wewnętrznych, Duchownych i Oświecenia Publicznego, trzech dyrektorów: 1 - Wydziału Administracji Ogólnej, 2 - Wydziału Przemysłu i Kunsztów, 3 - Wydziału Wyznań i Oświecenia Publicznego, ponadto dyrektor Kancelarii oraz Naczelnik Biura Kontroli i Rachuby. Rada otrzymała szerokie kompetencje w sprawach organizacji szkolnictwa oraz kontroli całego procesu nauczania, przede wszystkim zaś jej zadaniem był dozór i opieka nad funduszami edukacyjnymi oraz cenzura książek i pism. W jej dziejach można wyróżnić trzy okresy działal-

\footnotetext{
${ }^{1}$ Российский Государственный Исторический Архив в Санкт Петербурге [RGIAP], фонд 733, опись 77, дела: 167 - Мемории Совета Народного Просвещения в Царстве Польском за 1845 g.; 198 - Мемории Совета Народного Просвещения в Царстве Польском за Memorii Soveta Narodnogo Prosveŝeniâ v Carstve Polskom za 1846 g.; 243 - Мемории Совета Народного Просвещения в Царстве Польском за 1848 g.; 271- Мемории Совета Народного Просвещения в Царстве Польском за 1849 g.; 301 - Мемории Совета Народного Просвещения в Царстве Польском за 1850 g.; 302 - Дело о розъяснении положения о Совете Народного Просвещения Царства Польского, об ограничении числа почетных членов Совета и об увольнении членов совета В. И. Козловского, А. И. Крузенштерна, Ф. И. Людике и Н. И. Павлищева (1850 r. - reorganizacja), 336 - Мемории Совета Народного Просвещения в Царстве Польском за 1851 g.; 357 - Мемории Совета Народного Просвещения в Царстве Польском за 1852 g.; 387 - Мемории Совета Народного Просвещения в Царстве Польском за 1853 g.; 406 - Мемории Совета Народного Просвещения в Царстве Польском за 1854 g.; 421 - Мемории Совета Народного Просвещения в Царстве Польском за 1855 g.; 440 - Мемории Совета Народного Просвещения в Царстве Польском за 1856 g.; 463 - Мемории Совета Народного Просвещения в Царстве Польском за 1857 g.; 486 Мемории Совета Народного Просвещения в Царстве Польском за 1858 g.; 504 - Мемории Совета Народного Просвещения в Царстве Польском за 1859 g.; Brak jest protokołów za 1847 r. W księdze inwentarzowej za ten rok pod numerem dieła 220 figurują raporty wizytatorów z inspekcji szkół średnich i niższych.

${ }^{2}$ Rada Wychowania Publicznego w Królestwie Polskim w latach 1845-1850. Protokoły posiedzeń. T. 1, Lata 1845 i 1846, wybór i oprac. E. Ku la, A. M a s a l s ki i, Łódź-Kielce 2014; Rada Wychowania Publicznego w Królestwie Polskim w latach 1845-1850. Protokoły posiedzeń. T. II, Lata 1848-1850, wybór i oprac. E. Ku l a i A. M a s s a l s ki , Łódź-Kielce 2015.
} 
ności: pierwszy od 30 września 1833 r. do przełomu lat 1839/40, drugi od początku 1840 r. do przełomu lat 1849/50 i trzeci od początku 1850 r. do 1867 r. (w latach 1861-1862 nosiła nazwę Tymczasowa Rada Wychowania i w latach 1862-1867 Rada Wychowania) ${ }^{3}$. W pierwszym okresie Rada podlegała głównemu dyrektorowi Komisji Rządowej Spraw Wewnętrznych, Duchownych i Oświecenia Publicznego.

Zgodnie z ustawą o Radzie Wychowania Publicznego w jej skład miało wchodzić także czterech członków stałych, tj. dwóch z duchowieństwa i dwóch radców etatowych, a także osoby mianowane przez cara na wniosek dyrektora Rady. Już w 1834 r. rozszerzono skład Rady przez wprowadzenie obu prezesów konsystorza wyznań ewangelickich w charakterze wirylistów. W tym czasie do kompetencji Rady należało: 1. opieka i zarząd nad wszystkimi instytucjami naukowymi, 2. podejmowanie decyzji o otwieraniu i zamykaniu placówek oświatowych, 3. wydawanie rozporządzeń szkolnych w ramach obowiązującego statutu, 4. wykładnia przepisów rządowych w wypadku próśb i sporów, 5. mianowanie nauczycieli i urzędników, którzy jej podlegali, 6. decydowanie o kwalifikacjach nauczycieli, 7. przedstawianie kandydatów na honorowych kuratorów i inspektorów szkolnych (praktycznie zapis martwy), 8. zatwierdzanie podręczników szkolnych i programów nauczania, 9. zaopatrywanie placówek oświatowych w książki i pomoce naukowe, 10. przyjmowanie raportów szkolnych, 11. wyznaczanie kar i nagród dla pracowników zatrudnionych w placówkach szkolnych, 12. udzielanie zgody osobom prywatnym na zakładanie szkół i pensjonatów, 13. opiniowanie rachunków związanych z wydatkami na cele oświatowe, 14. ustalanie budżetów (w tym płace dla nauczycieli) na utrzymanie placówek oświatowych, 15. przygotowywanie ogólnych raportów o stanie szkolnictwa w Królestwie Polskim, 16. nadzór nad zapisami prywatnymi na cele oświatowe ${ }^{4}$. Ponadto na polecenie Namiestnika Królestwa Polskiego, Iwana Paskiewicza ${ }^{5}$, Rada przejęła nadzór nad sprawami cenzury i handlu książkami. Posiedzenia Rady odbywały się dwa razy w tygodniu. Rada miała sekretarza, który prowadził protokoły zebrań6

${ }^{3}$ T. Manteuffel: Centralne władze oświatowe na terenie b. Królestwa Kongresowego (1817-1915), Warszawa 1929, s. 63, 66; Rada Wychowania Publicznego w Królestwie Polskim w latach 1845-1850. Protokoły posiedzeń, t. 1, Lata 1845 i 1846, wybór i oprac. E. Ku la, A. M a s salski, Łódź-Kielce 2014, s. 9-11; K. Po z nań ski: Oświata i szkolnictwo w Królestwie Polskim 1831-1869. Lata zmagań i nadziei. T. 1, Przebudowa systemu szkolnictwa i wychowania w Królestwie Polskim w latach 1831-1839, Warszawa 2001, s. 81-87.

${ }^{4}$ Rada Wychowania Publicznego w Królestwie Polskim w latach 1845-1850. Protokoły posiedzeń. T. 1, s. 9-11.

5 Feldmarszałek, Książę Warszawski Iwan Paskiewicz (1782-1856), wyznania prawosławnego, w latach 1832-1856 Namiestnik Królestwa Polskiego. Jako wódz naczelny wojsk Imperium Rosyjskiego, w kampanii 1830-1831 przeciwko Polsce stłumił powstanie listopadowe. Sprawował władzę naczelną jako generał-gubernator Królestwa Polskiego. [M.] Szczerbatow: Rządy księcia Paskiewicza w Królestwie Polskim (1832-1847), Warszawa 1900.

${ }^{6}$ T. Manteuffel: Centralne władze oświatowe s. 31-32; T. Demidowicz: Rada Wychowania Publicznego jako „główna zwierzchność szkolna” w Królestwie Polskim 18331839/40 „Przegląd Historyczno-Oświatowy” 1992 z. 1-2 s. 72. 
W drugim okresie, po utworzeniu w 1840 r. Warszawskiego Okręgu Naukowego, Rada stała się jednym ze składników zarządu tego Okręgu, organem doradczym kuratora. Utrzymane kompetencje Rady miały charakter formalny, podzielono je bowiem między kuratora, Radę Wychowania Publicznego oraz naczelnika administracji WON. Wobec braku rozstrzygnięć dotyczących wewnętrznej organizacji Rady obradowała ona w dawnym składzie i sama opracowała projekt nowej organizacji, odrzucony przez ministra w $1841 \mathrm{r}$. Przeredagowany projekt ostatecznie zatwierdzony został przez ministra 12 kwietnia 1842 r. Nieco poszerzone kompetencje Rady Wychowania były następujące: 1 . omawianie projektów nowych praw i przepisów, 2. przygotowywanie raportów ogólnych i specjalnych dotyczących szkolnictwa w Królestwie Polskim, 3. interpretowanie przepisów w dziedzinie oświaty, 4. przygotowywanie budżetów WON, 5. zakładanie instytucji oświatowych i naukowych oraz sprawy związane z ich bytem materialnym, 6. nadzór nad organizowaniem, zakładaniem i zamykaniem szkół prywatnych oraz udzielanie zezwoleń na prywatne nauczanie, 7. sprawdzanie kwalifikacji nauczycieli szkół półwyższych, średnich i niższych, 8. nadzór nad przygotowywaniem podręczników i pomocy naukowych, 9. prowadzenie śledztw w sprawach wykroczeń i nadużyć urzędników i nauczycieli oraz sprawy karności szkolnej, 10. udzielanie pochwał i nagan, patentów szkolnych, nagród i promocji uczniów do klas wyższych, 11. opiniowanie w sprawach emerytur, zwalnianie urzędników, oddawanie pod sąd urzędników, nauczycieli i innego personelu oświatowego, 12. zaopatrywanie szkół w pomoce naukowe, 13. zawieranie kontraktów z dostawcami, 14. cenzura z wyjątkiem periodyków i gazet, 15. nadzór nad legatami i zapisami prywatnymi na cele oświatowe, 16. nadzór nad handlem książkami, 17. rozpatrywanie wszelkich spraw wniesionych przez Kuratora, 18. urządzenie dozoru nad szkołami elementarnymi, 19. podejmowanie decyzji w sprawie zwolnienia ubogich uczniów od opłat szkolnych, 20. zmiany w zakresie programów szkolnych, 21. zatwierdzanie podziału przedmiotów pomiędzy nauczycieli gimnazjów ogólnych i Gimnazjum Realnego, 22. nadzór nad działalnością Instytutu Gospodarstwa Wiejskiego i Leśnictwa. Protokół obrad, a właściwie dziennik czynności Rady, miał być prowadzony przez dyrektora Kancelarii Okręgu wobec zniesienia urzędu sekretarza Rady ${ }^{7}$.

Od 1849 r. Rada Wychowania etatem z dnia 14 sierpnia 1849 r. miała zmieniony skład osobowy, wprowadzono bowiem czterech płatnych członków, którzy mieli być zarazem wizytatorami generalnymi. Zmiany polegały na upodobnieniu Rady w Królestwie Polskim do Rad Kuratorów innych okręgów w Imperium. Na skutek interwencji kuratora Warszawskiego Okręgu Naukowego, Mikołaja Okuniewa ${ }^{8}$, ukazem

${ }^{7}$ T. Manteuffel: Centralne władze oświatowe s. 34-36; Rada Wychowania Publicznego w Królestwie Polskim w latach 1845-1850. Protokoły posiedzeń. T. 1 s. 9.

${ }^{8}$ Mikołaj Okuniew (1788-1850), wyznania prawosławnego. Generał major/lejtnant armii rosyjskiej, uczestnik kampanii napoleońskiej i wojny polsko-rosyjskiejw 1830-1831.Od1837r. członek Komisji Rządowej Spraw Wewnętrznych, Duchownych i Oświecenia Publicznego 
cesarskim z 1850 r. utrzymano członków honorowych Rady Wychowania, którymi mieli zostać: przedstawiciel duchowieństwa katolickiego w osobie rektora Akademii Duchownej Rzymskokatolickiej w Warszawie oraz dwóch lub trzech innych członków zajmujących wyższe stanowiska w szkolnictwie.

W trzecim okresie działalności Rady Wychowania, utworzonej w 1862 r., członkowie przybrani mieli być wynagradzani za swoją pracę. Byli to duchowni, przełożeni wyższych zakładów naukowych, profesorowie i specjaliści w różnych dziedzinach nauki i kształceniu młodzieży. Pierwsze posiedzenie Rady, wyznaczone na 15 stycznia 1863 r., nie doszło do skutku na skutek wybuchu powstania, następne zwołano po 9 miesiącach, 20 października 1863 r. Uchwalono wtedy wewnętrzny regulamin pracy Rady9 . Po 1867 r., kiedy ponownie utworzono Warszawski Okręg Naukowy i zmienił się sposób zarządzania szkolnictwem w Królestwie Polskim, Rada Wychowania przestała istnieć.

Wszystkie posiedzenia Rady Wychowania Publicznego były protokołowane. Każdy uczestniczący w posiedzeniu miał prawo zgłaszania na piśmie swego zdania odrębnego, a protokoły miały być podpisywane przez prezydującego i wszystkich obecnych na posiedzeniu członków Rady. W praktyce jednak spotykamy w rękopiśmiennych protokołach jedynie podpis prezydującego, składany raz w miesiącu pod ostatnim protokołem. Protokolanci spisujący treść obrad czynili to często dość niedbale, stąd w tekście znajduje się wiele uchybień, polegających na niedokładnym zapisie nazwisk (często zmienione jest wielokrotnie ich brzmienie w poszczególnych protokołach, np. nazwisko Zeidel występuje też jako Seibel, Zejdel, Zejdler). Przy większości nazwisk nie podawane są imiona ${ }^{10}$.

W czasach Księstwa Warszawskiego oraz Królestwa Polskiego doby konstytucyjnej, dzięki osobom pamiętającym czasy Komisji Edukacji Narodowej, działacze tacy jak Stanisław Staszic starali się w jak największym stopniu korzystać z doświadczeń krajów Europy Zachodniej w dziedzinie edukacji. Szkoła elementarna do początku lat dwudziestych XIX w. nie odbiegała poziomem od tego typu szkół w krajach zachodnioeuropejskich. Nie wszystkie jednak przyjęte rozwiązania były dla Polski korzystne. Izba Edukacji Publicznej poddana została, na wzór francuski administrowania szkolnictwem, dyrektorowi spraw wewnętrznych, co oznaczało zerwanie w tym zakresie z polską tradycją samodzielnego resortu oświaty. Rektor Uniwersytetu Warszawskiego, ks. Wojciech Anzelm Szweykowski, w mowie wygłoszonej 14 maja 1818 r. podczas inauguracji pierwszego roku akademickiego podkreślił zasadę

Królestwa Polskiego. W 1839-1850 kurator WON. T. Mante uffel: Centralne władze s. 61, 89; K. Poznań ski: Oświata i szkolnictwo w Królestwie Polskim 1831-1869. Lata zmagań i nadziei. T. 3, Polityka oświatowa caratu w latach 1834-1861, Warszawa 2004, s. 62-64.

${ }^{9}$ T. De mid owicz: Rada Wychowania Publicznego s. 67-81; T. Mante uffel: Centralne władze oświatowe, s. 32-37.

${ }^{10}$ Rada Wychowania Publicznego w Królestwie Polskim w latach 1845-1850. Protokoły posiedzeń, t. 1, s. 548, tamże, t. 2, s. 11, 89 i nast. 
wolności nauki, jaka powinna być w tej uczelni przestrzegana. Stopnie akademickie uzyskane na zagranicznych uczelniach, musiały być, z wyjątkiem stopni uzyskanych w Uniwersytecie Krakowskim, nostryfikowane ${ }^{11}$. Pierwsze ograniczenia dotyczące swobody studiowania miały miejsce w konstytucyjnym Królestwie Polskim, kiedy po 1818 r. nasilił się nadzór policyjny nad młodzieżą, a w 1822 r. ogłoszony został ukaz o zakazie wstępowania na zagraniczne uniwersytety poddanym Królestwa. Jednak zarówno w czasach Księstwa Warszawskiego, jak i konstytucyjnego Królestwa Polskiego byli wysyłani zagranicę stypendyści, których po wydoskonaleniu się w naukach i sztuce zatrudniano w charakterze nauczycieli w szkołach średnich i wyższych. Do pierwszych stypendystów należeli m. in. Adam Kitajewski, wysłany w 1809 r. do Berlina, Michał Szubert, Jan Huisson i Józef Tomaszewski w tym samym roku wysłani do Paryża (J. Tomaszewski początkowo był w Freibergu). Ze względu na sytuację polityczną kolejną grupę stypendystów władze edukacyjne Księstwa wysłały dopiero w 1814 r. Karol Skrodzki i Jan Kanty Krzyżanowski wyjechali na studia do Anglii, a po miesiącu udali się do Holandii i Niemiec, gdzie uczęszczali na wykłady w Getyndze i Lipsku. Pod koniec 1815 r. kilka miesięcy obaj studiowali w Paryżu. W 1814 r. roczne stypendium otrzymał Franciszek Armiński, studiujący w Paryżu, a w 1815 r. Feliks Jarocki i ks. Rafał Skolimowski otrzymali stypendium na studia w Paryżu (F. Jarocki rozpoczął studia w Uniwersytecie w Berlinie) ${ }^{12}$. W latach 1816-1826 wyjechało na stypendia zagraniczne blisko 100 absolwentów szkół wyższych, z których wielu zostało po powrocie profesorami w macierzystych szkołach $^{13}$. Lata konstytucyjne Królestwa były najkorzystniejszym w XIX wieku okresem rozwoju nauki polskiej.

Jednym z pierwszych posunięć władz po upadku powstania listopadowego było zamknięcie między innymi Uniwersytetu Warszawskiego i wszystkich wyższych oraz średnich szkół Królestwa Polskiego. Uruchomione w miejsce tych ostatnich tymczasowe, czteroklasowe szkoły wydziałowe, funkcjonowały tylko rok, a następnie w roku 1832/33 ich działalność została zupełnie zawieszona. Należy podkreślić, że w owym czasie uniwersytety w Europie Zachodniej, a także w Rosji, zarówno poprzez wykładowców, jak i studentów, odgrywały znaczącą rolę w dziedzinie upowszechniania nauki. Po upadku powstania listopadowego ogromna fala tzw. Wielkiej Emigracji reprezentowała cały naród i stanowiła jego rzeczywistą elitę intelektualną, która emigrowała w celu kontynuowania walki o Polskę. Współpracowała z emigracją lub też znalazła się na emigracji prawie cała elita intelektualna i artystyczna kraju. Doszło wówczas do rzadkiego fenomenu, że w ćwierćwieczu po 1831 r. najważniejsze polskie dzieła i osiągnięcia artystyczne powstawały poza gra-

${ }^{11}$ A. Winiarz: Szkolnictwo Księstwa Warszawskiego i Królestwa Polskiego (1807-1831), Lublin 2002, s. 18, 510.

${ }^{12}$ Historia Nauki Polskiej, red. B. Suchodolskiego, t. III, Wrocław-Gdańsk 1977, s. 25-27.

13 A. Massalski: Stypendyści zagraniczni Królestwa Polskiego w czasach Stanisława Staszica. Zarys problemu „Rozprawy z Dziejów Oświaty” t. 45: 2006 s. 113-114. 
nicami kraju. Podobnie było w dziedzinie twórczości naukowej, zwłaszcza w zakresie szeroko pojętej humanistyki ${ }^{14}$. Po klęsce powstania listopadowego polscy uczeni nie mieli dostępu do działających powszechnie w Europie instytucji naukowych. Ich działalność naukowa opierała się więc najczęściej na inicjatywie poszczególnych osób bądź zespołów. Podejmowano też próby organizowania pracy naukowej na emigracji, przede wszystkim w Paryżu, gdzie w 1832 r. powstało Towarzystwo Literackie, a w 1838 r. powołano Bibliotekę Polską. Warunki polityczne w latach międzypowstaniowych odsuwały Polaków od uczestnictwa w zorganizowanym życiu naukowym. Mimo to w wielu dziedzinach byli oni szczególnymi pośrednikami w kontaktach pomiędzy Wschodem a Zachodem, działając poza oficjalnym życiem naukowym. Nieliczna grupa adiunktów zlikwidowanego Uniwersytetu Warszawskiego oraz profesorowie Szkoły Przygotowawczej do Instytutu Politechnicznego zatrudnieni zostali w szkolnictwie średnim. Studia na uniwersytetach europejskich utrudniano, a absolwenci tych uczelni nie byli przyjmowani do pracy w administracji państwowej. Takie ograniczenia dotyczyły również słuchaczy Uniwersytetu Jagiellońskiego. Popierano zaś studia na uniwersytetach rosyjskich, dlatego zaczęto wysyłać corocznie 10 stypendystów rządowych z Królestwa (od 1837 r. liczbę tę zwiększono do 15) do uniwersytetów Petersburskiego i Moskiewskiego, w celu przygotowania ich na nauczycieli gimnazjalnych ${ }^{15}$.

Jak wynika z powyższych rozważań, związki naukowe i oświatowe Królestwa Polskiego z krajami Europy Zachodniej zostały radykalnie ograniczone w latach po upadku powstania listopadowego do wybuchu powstania styczniowego (18311863). Znalazło to także odzwierciedlenie w protokołach posiedzeń Rady Wychowania Publicznego, z których wynika, że tylko incydentalnie uczeni i nauczyciele Królestwa Polskiego wyjeżdżali zagranicę w celach naukowych, natomiast większość decyzji Rady związanych z kontaktami zagranicznymi dotyczyła zakupu eksponatów i obiektów a także, znacznie rzadziej, czasopism dla jednostek badawczych, takich jak Ogród Botaniczny, Gabinet Zoologiczny czy Biblioteka Publiczna.

W czasie posiedzeń Rady Wychowania Publicznego aż 17 razy podejmowano decyzję w sprawie zakupu eksponatów do Ogrodu Botanicznego w Warszawie od różnych ogrodników z państw niemieckich i raz od ogrodnika z Holandii. Ogród Botaniczny utworzony został w grudniu 1818 r. po przeniesieniu jego zaczątku z terenów przy Pałacu Kazimierzowskim do Ogrodu Królewskiego obok Belwederu. Ogrodem kierował prof. Michał Szubert, posiadający duże kwalifikacje uzyskane podczas studiów w Paryżu. Ogród powstał z myślą o potrzebach przede wszystkim Szkoły

${ }^{14}$ L. Zasztowt: Popularyzacja nauki w Królestwie Polskim 1864-1905. Wrocław-Łódź 1989, s. 8-9; E. Kula: Naukowa, literacka i artystyczna twórczość nauczycieli rzq̨dowych męskich szkół średnich Królestwa Polskiego w latach 1833-1862, Kielce 2006, s. 17-18.

${ }^{15}$ Historia Nauki Polskiej, t. III, s. 170-173; L. Z a s ztowt: Wstęp, [w:] Akademie nauk. Uniwersytety. Organizacje nauki. Polsko-rosyjskie relacje $w$ sferze nauki XVIII-XX w., red. L. Z a s z towt, Warszawa 2013, s. 12, 27. 
Lekarskiej, ale korzystały z niego i inne zakłady naukowe Warszawy. W czasie, kiedy M. Szubert nadzorował działalność ogrodu, było tam około 40 drzew i krzewów oraz ponad 200 roślin wieloletnich, założona była także winnica ${ }^{16}$. Reskryptem cara Aleksandra I z 1825 r. Ogród Botaniczny podporządkowany został z dniem 1 stycznia 1826 r. Komisji Rządowej Wyznań Religijnych i Oświecenia Publicznego. M. Szubert rozbudowywał Ogród, a brakujące rośliny sprowadzał z zagranicy. Wraz z uczniami w czasie podróży po kraju zbierał też rośliny dziko rosnące i przesadzał je na teren Ogrodu Botanicznego. Po powstaniu listopadowym niemal dwie trzecie Ogrodu przyłączono do Parku Łazienkowskiego, a nadzór nad działalnością tej placówki sprawowali Rosjanie.

Najczęściej, albowiem dziesięciokrotnie, rozpatrywano sprawy zakupu różnego rodzaju roślin, w tym nasion a także cebulek roślin i drzewek u ogrodnika Jakuba Zeidela w Dreźnie. Czterokrotnie dokonywano zakupów w Erfurcie u Fryderyka Haage oraz raz w Lipsku u ogrodnika Creifa (Krejfa) i raz w Berlinie u ogrodnika Krojusa. Wszystkie te transakcje przeprowadzano za pośrednictwem banku Fraenkelów (Antoni Fraenkel występuje omyłkowo w protokołach Rady jako Jan Frenkiel), polskich kupców i bankierów żydowskiego pochodzenia. W banku tym mieli swe konta ambasadorowie innych państw, a ponadto finansowane były przezeń inne przedsiębiorstwa dostawców rządowych ${ }^{17}$. Desygnowane sumy na zakup eksponatów do ogrodu botanicznego wahały się od 20 talarów do 137 talarów (9 razy decydowano o wypłacie w talarach) ${ }^{18}$. Najwyższa transakcja dotyczyła zakupienia w $1849 \mathrm{r}$. u ogrodnika Jakuba Zeidela cebulek azalii, palm i innych roślin ${ }^{19}$. Sześć transakcji przeprowadzono w rublach, i wynosiły one od 32 do 314 rubli. Najwyższa kwota (była to półroczna pensja średnio zarabiającego nauczyciela gimnazjum ${ }^{20}$ ) wypłacona była Zeidelowi w Dreźnie za cebulki kwiatów i innych roślin oraz drzewek ${ }^{21}$. Jedynie w wypadku wypłaty ogrodnikowi w Sassenheis koło Lejdy w Holandii, Cruiferowi, środkiem płatniczym były holenderskie floreny. Otrzymał on wiosną 1845 r. 98 holenderskich florenów i 6 centów za dostawę cebulek roślin do warszawskiego Ogrodu Botanicznego ${ }^{22}$.

Drugą instytucją, w sprawie której Rada Wychowania Publicznego podejmowała decyzje wiążące się z kontaktami z krajami zachodniej Europy, był Gabinet Zoo-

${ }^{16}$ J. Bi elińs ki: Królewski Uniwersytet Warszawski (1816-1831), t. I, Warszawa 1907, s. $432-433,460$.

${ }^{17}$ A. Eisen ba ch: Emancypacja Żydów na ziemiach polskich 1785-1870 na tle europejskim. Warszawa 1988, s. 227.

${ }^{18} 1$ talar $=3$ zł.

${ }^{19}$ Rada Wychowania Publicznego w Królestwie Polskim w latach 1845-1850. T. 2, s. 260.

${ }^{20}$ A. Massalski: Wstęp, [w:] A. Massalski: Stownik biograficzny. Nauczyciele szkót średnich rządowych męskich w Królestwie Polskim 1833-1862, Warszawa 2007, s. 25.

${ }^{21}$ Rada Wychowania Publicznego w Królestwie Polskim w latach 1845-1850. T. 2, s. 89.

${ }^{22}$ Rada Wychowania Publicznego w Królestwie Polskim w latach 1845-1850. T. 1, s. 87. 
logiczny w Warszawie. Gabinet ten rozpoczął działalność w 1818 r., kiedy Komisja Wyznań Religijnych i Oświecenia Publicznego Królestwa Polskiego nabyła pierwszą kolekcję zoologiczną liczącą ponad 20 tysięcy okazów. Materiały przyrodnicze zakupiono od sukcesorów śląskiego barona Sylwiusza Münkwitza. Zapoczątkowały one jedną z największych kolekcji zoologicznych w Europie. W pierwszym okresie, tj. w latach 1818-1862, czyli do emerytury, gabinetem kierował zoolog Feliks Paweł Jarocki (1790-1865). W tym czasie zbiory umieszczone w Pałacu Kazimierzowskim były systematycznie porządkowane i opracowywane. F. P. Jarocki stale je uzupełniał i powiększał, dokonując zakupów m.in. u Georga Dahla w Wiedniu, u Wilhelma Feldnera okazy owadów przywiezione z Brazylii czy u prof. Martina Lichtensteina w Berlinie kolekcję ptaków. Mimo zamknięcia Uniwersytetu Warszawskiego w wyniku powstania listopadowego, Gabinet dzięki staraniom F. P. Jarockiego zachował zbiory w stanie nienaruszonym. Gabinet pełnił do 1855 r. wyłącznie funkcję dydaktyczną, nie prowadzono w nim badań naukowych. Był pomocą na studiach zoologicznych, a także służył uczniom warszawskich szkół średnich ${ }^{23}$. Początkowo do końca $1848 \mathrm{r}$. do Gabinetu Zoologicznego sprowadzane były różnego rodzaju okazy od Szyca [?] z Drezna. Wypłacone mu sumy świadczyły o dużej wartości tych zakupów, bowiem otrzymywał on w trzech transakcjach: raz 300 talarów, po raz drugi 270 talarów i za trzecim razem 299 rubli srebrnych. Za te sumy Gabinet Zoologiczny nabył 23 egzemplarze okazów brakujących, a odkrytych w owym czasie w Nowej Zelandii, Nowej Gwinei, Borneo i Nowej Irlandii, a także rzadkie okazy wypchanych ptaków. Kolejnym kontrahentem, który dostarczał różnego rodzaju eksponaty do Gabinetu Zoologicznego był Ferdynand Szulc także z Drezna, z którym zawarto w 1849 r. dwie transakcje, i w 1850 r. - także dwie. Najwyższa suma, którą otrzymał, to 322 talary za pozyskanie obiektów „egipskiej historii”, a także za wypchane ptaki. Łącznie z tytułu dokonywanych zakupów dla Gabinetu Zoologicznego do Drezna trafiło 1330 talarów oraz ok. 325 rubli srebrnych ${ }^{24}$.

O ile przed powstaniem listopadowym ważną rolę w kontaktach ze światem zachodniej Europy stanowiły książki i czasopisma, to po jego upadku ta dziedzina życia społecznego w sposób drastyczny uległa ograniczeniu. Wpłynął na to fakt, że zamknięty został Uniwersytet Warszawski, którego zbiory zostały wywiezione do Petersburga, a z katalogu książek używanych przez szkoły średnie usunięto książki francuskie, zastępując je w miarę upływu czasu książkami autorów rosyjskich ${ }^{25}$.

${ }^{23}$ J. B i eliński: Królewski Uniwersytet Warszawski (1816-1831), t. I, Warszawa 1907, s. 515-538; Z. Fe d o r o w i c z, S. Feli ks i a k: 150-lecie Gabinetu Zoologicznego w Warszawie (1818-1968), „Memorabilia Zoologica” Nowa Seria t. 1: 2016 s. 15, http://www.muzeum. uw.edu.pl/uw-w-zrodlach-o-150-leciu-gabinetu-zoologicznego/ [dostęp 6. 08. 2017]

${ }^{24}$ Rada Wychowania Publicznego w Królestwie Polskim w latach 1845-1850. T. 2, s. 31, 64, 142, 196, 290, 371, 421.

${ }^{25}$ J. K u c h ar z e w s k i : Epoka paskiewiczowska w Królestwie Polskim. Losy oświaty. WarszawaKraków 1914, s. 60-61, 77-98. 
W Warszawie po powstaniu listopadowym wiodącą biblioteką stała się biblioteka Warszawskiego Okręgu Naukowego. Była ona spadkobierczynią dawnej biblioteki publicznej, powstałej 24 marca 1818 r., w wyniku przekształcenia reskryptem cara Biblioteki działającej przy Uniwersytecie Królewskim. Na wniosek Komisji Rządowej Wyznań Religijnych i Oświecenia Publicznego powołano na jej dyrektora wybitnego leksykografa, Bogumiła Samuela Linde. Jego zastępcą został Joachim Lelewel. Do zasobów biblioteki włączony został cenny księgozbiór Liceum Warszawskiego, w którym znajdowały się zbiory po Szkole Rycerskiej, a także po Ignacym Krasickim, Szkole Prawa i Administracji oraz większość zasobów Biblioteki przy Sądzie Apelacyjnym. W 1825 r. uzupełniony został księgozbiór matematyczno-przyrodniczy zasobami po Szkole Lekarskiej. W 1819 r. biblioteka uzyskała prawo do egzemplarza obowiązkowego, stąd otrzymywała bieżące wydawnictwa z terenu Królestwa Polskiego. Pozyskała też księgozbiory kasowanych klasztorów (około 50 tysięcy woluminów). W chwili zamknięcia Uniwersytetu w 1831 r. biblioteka liczyła ok. 134000 woluminów druków, 2000 rękopisów i ponad 102 tysiące jednostek w Gabinecie Rycin. Większość zbiorów oraz katalogi i inwentarze wywieziono wtedy do Petersburga ${ }^{26}$.

W sprawie nabytków dla biblioteki Rada rozpatrywała wnioski władz Warszawskiego Okręgu Naukowego dwukrotnie. W 1845 r. podjęto decyzję o wypłaceniu sumy 63 rubli srebrnych księgarzowi Augustowi Emanuelowi Glüksbergowi za egzemplarze zeszytów 23-77 „Galerii Drezdeńskiej”, dostarczonych do Biblioteki Rządowej. Rok później zatwierdzono do wypłaty Kasie Urzędu Pocztowego w Warszawie dodatek za prenumeratę dla Biblioteki Rządowej na 1846 r. czasopisma „The Edinbourg review” (wydawany w Edynburgu w latach 1802-1929 magazyn naukowo-kulturalny) kwotę 1 rubli srebrnych 65 kopiejek z sum rezerwowych ${ }^{27}$.

Placówką oświatową, która kilkakrotnie stanowiła przedmiot obrad Rady Wychowania Publicznego w różnych sprawach było Gimnazjum Realne w Warszawie. Gimnazjum to założono w 1840 r. w celu „przysposobienia młodzieży do powołań przemysłowych". Planowano też utworzenie szkół realnych z planem nauk odpowiadającym potrzebom władz rosyjskich w Królestwie Polskim. W Gimnazjum Realnym było siedem klas jednorocznych, w których realizowano bardzo obszerny i zróżnicowany treściowo program nauczania ${ }^{28}$. W klasie VII uczono ponadto w celu wydo-

\footnotetext{
${ }^{26}$ J. Bieliń ski: Królewski Uniwersytet Warszawski (1816-1831), t. I, s. 742-760.

${ }^{27}$ Rada Wychowania Publicznego w Królestwie Polskim w latach 1845-1850. Protokoły posiedzeń. T. 1, s. 152-153, 510.

${ }^{28}$ W gimnazjum realnym realizowano przedmioty: 1) religia oraz historia święta i kościelna; 2) j. rosyjski; 3) j. polski; 4) j. niemiecki; 5) arytmetyka; 6) arytmetyka z zastosowaniem; 7) geometria; 8) algebra; 9) trygonometria; 10) sekcje konieczne; 11) geometria opisująca; 12) mechanika; 13) historia naturalna; 14) fizyka doświadczalna; 15) chemia teoretyczna i praktyczna; 16) geografia popularna; 17) układanie anszlagów (projektów), rachunków i pisanie listów; 18) buchalteria ekonomiczna; 19) kaligrafia; 20) rysunki malarskie i linearne; 21) gimnastyka. K. P o z n a ń s k i : Oświata i szkolnictwo w Królestwie Polskim 1831-1869. Lata zmagań i nadziei. T. 3, s. 117.
} 
skonalenia uczniów malarstwa, farbiarstwa, sztuki wyrabiania cukru, destylowania, górnictwa, fabrykacji nawozów chemicznych oraz tzw. mechanizmu praktycznego machin używanych w fabrykach. Przy tej szkole planowano urządzenie biblioteki oraz gabinetów zbiorów narzędzi matematycznych, fizycznych i technicznych. Środki finansowe przyznane szkole obejmowały tylko płace dla nauczycieli i personelu pomocniczego, nie uwzględniono zaś funduszy na wyposażenie w urządzenia, narzędzia i pomoce naukowe ${ }^{29}$. W Gimnazjum Realnym zdecydowanie ograniczono nauczanie przedmiotów humanistycznych oraz całkowicie pominięto wykłady historii ojczystej. Nauczyciele tej szkoły mieli zapewniony kontakt z europejską myślą naukową poprzez zaprenumerowane dla nich naukowe czasopisma angielskie, francuskie i niemieckie ${ }^{30}$. Co ciekawe, Rada Wychowania Publicznego rozpatrywała wnioski w sprawie Gimnazjum Realnego jedynie w 1845 r. W latach późniejszych szkoła ta nie jest wymieniana w protokołach. Po raz pierwszy Rada podjęła decyzję w sprawie gimnazjum w marcu 1845 r., bowiem wówczas zatwierdzono wypłatę przez bank Fraenkela 33 talarów [?] Wejchertowi z Lipska za różne pomoce naukowe, przeznaczone dla pracowni mechanicznej tej szkoły a także o zakupie dla niej maszyny służącej do strugania metalu, którą sprowadzono z Belgii od mechanika [?] Hammana. Po raz drugi dwa miesiące później zatwierdzono 52 ruble srebrne za instrumenty z zakresu mechaniki, dostarczone do Gimnazjum Realnego. Miesiąc później okazało się, iż dostarczono do tej szkoły egzemplarz zeszytów 59-66 zbioru obrazów znakomitych malarzy, których dzieła znajdowały się w monachijskiej Starej Pinakotece. Jak już wcześniej wspomniano, drugi egzemplarz tego zbioru znalazł się w Bibliotece Publicznej ${ }^{31}$.

Jedyny raz na kartach protokołów posiedzeń Rady Wychowania Publicznego w omawianym czasie pojawiła się na wiosnę 1846 r. Szkoła Sztuk Pięknych. Została ona otwarta w Warszawie w 1844 r. Umieszczona była w salach, zajmowanych wcześniej przez Oddział Sztuk Pięknych Uniwersytetu Warszawskiego, tj. w 5 salach z amfiteatrem w gmachu Gabinetu Zoologicznego. Pierwszym dyrektorem Szkoły został, sprawujący podobną funkcję w Gimnazjum Realnym, Karol Frankowski, a po jego śmierci w 1846 r. Filip von Stender. Pierwszym inspektorem był Francuz Karol Sestié, a od 1848 r. Edward Matecki. Szkole przekazano uporządkowane zbiory Oddziału Sztuk Pięknych Uniwersytetu, co dało początek szkolnej galerii. Szkoła posiadała trzy oddziały: architektury, rzeźby i malarstwa. Kształcono tam na poziomie wyższym niż przewidziany ustawą poziom szkoły średniej. Dawała dobre przygotowanie techniczne, a oddział malarstwa przygotował przede wszystkim nauczycieli

\footnotetext{
${ }^{29}$ Tamże, s. 118.

${ }^{30} \mathrm{~J}$. M i ą s o : Szkoły realne w Królestwie Polskim w okresie międzypowstaniowym, „Rozprawy z Dziejów Oświaty" t. 6: 1963 s. 93-123.

${ }^{31}$ Rada Wychowania Publicznego w Królestwie Polskim w latach 1845-1850. T. 1, s. 110, 152-153, 198.
} 
rysunków dla szkół średnich ${ }^{32}$. Formalnie Szkołę zamknięto w 1866 r., a jej tradycje kontynuowała otwarta w 1865 r. Klasa Rysunkowa. Rada Wychowania Publicznego rozpatrywała wniosek kierownictwa Warszawskiego Okręgu Naukowego w sprawie uregulowania bankowi Fraenkela należności za podatek, pochodzący z opłat poniesionych za sprowadzenie z Gdańska (wówczas Prusy) do Szkoły Sztuk Pięknych ośmiu gipsowych modeli. Przeznaczono na to sumę 8 rubli 84 kopiejki, które pochodziły z opłat uczniowskich ${ }^{33}$.

Podobnie tylko jednokrotnie w protokołach Rady Wychowania Publicznego pojawia się wniosek w sprawie Instytutu Gospodarstwa Wiejskiego i Leśnictwa. Uczelnia początkowo występowała pod nazwą Szkoły Agronomicznej. Oficjalne otwarcie nastąpiło w 1820 r., ale pod inną, ostateczną już nazwą - Instytut Agronomiczny. Instytut Agronomiczny składał się początkowo z jednej klasy, która kształciła przyszłych ekonomów i zarządców większych dóbr. W 1822 r. nastąpiła reorganizacja Instytutu. Od tej pory uczelnia prowadziła kształcenie na dwóch poziomach nauczania: wyższym (dla przyszłych ekonomów i zarządców dóbr oraz synów właścicieli ziemskich) oraz elementarnym (dla przyszłych kwalifikowanych robotników - parobków, owczarzy, gorzelanych itp.). W wyniku upadku powstania listopadowego władze rosyjskie zamknęły wszystkie szkoły wyższe i zawodowe w Królestwie Polskim, w tym Instytut Agronomiczny, który został przywrócony do życia w $1836 \mathrm{r}$. W 1840 r. uczelnię zreorganizowano przez dodanie wydziału leśnego i przekształcenie jej w Instytut Gospodarstwa Wiejskiego i Leśnictwa ${ }^{34}$. W maju 1850 r. kierownictwo Warszawskiego Okręgu Naukowego w wyniku raportu dyrektora Instytutu ${ }^{35}$ wystąpiło do Rady o zaprenumerowanie dla biblioteki tej szkoły czasopisma „Agronomische Zeitung" wydawanego w Lipsku przez dr. Wilhelma von Hamm (czasopismo ukazywało się w latach 1847-1848), w miejsce prenumerowanego wcześniej „Oekonomische Neuigkeiten und Verhandlungen" (wydawanego w Pradze w języku niemieckim w latach 1811-1850 ${ }^{36}$. Również przedmiotem obrad Rady Wychowania Publicznego była sprawa prenumeraty czasopism dla członków Komitetu Egzaminacyjnego $^{37}$. Po raz pierwszy kwestią tą zajęła się Rada 1/13 sierpnia $1849 \mathrm{r}$.

${ }^{32}$ I. Jakimowicz, A. Rys zkiewicz: Szkoła Sztuk Pięknych w Warszawie 1844-1866, „Rocznik Warszawski” t. 4: 1963, [druk.] 1964 s. 56-113.

${ }^{33}$ Rada Wychowania Publicznego w Królestwie Polskim w latach 1845-1850. T. 1, s. 377.

${ }^{34}$ K. Poznański: Oświata i szkolnictwo w Królestwie Polskim 1831-1869. Lata zmagań i nadziei. T. 3 s. 97-106.

35 Michał Oczapowski (1788-1854), prekursor rozwoju nowoczesnego rolnictwa na ziemiach polskich. Profesor rolnictwa na Uniwersytecie w Wilnie, w latach 1836-1853 dyrektor Instytutu Gospodarstwa Wiejskiego i Rolnictwa. Z. Kosiek: Oczapowski Michał (1788-1854), PSB, t. 23, s. 522-525.

${ }^{36}$ Rada Wychowania Publicznego w Królestwie Polskim w latach 1845-1850. T. 2, s. 360.

${ }^{37}$ Komitet Egzaminacyjny utworzony został przez Radę Administracyjną 16 lipca 1835 r. $\mathrm{Na}$ jego czele stanął Samuel Bogumił Linde. Komitet składał się z sekcji filologicznej i matematyczno-fizycznej, a na członków miano wybierać ośmiu profesorów spośród 
na wniosek kierownictwa Warszawskiego Okręgu Naukowego, w wyniku raportu przewodniczącego Komitetu Egzaminacyjnego. Prosił on o zaprenumerowanie dla użytku tego Komitetu pierwszej serii czasopisma pt. „L'Institut des Sciences Mathematiques Phisiques et Naturelles" (Paryż 1837, 1840). Rada Wychowania Publicznego zatwierdziła ten wniose ${ }^{38}$.

Po raz drugi prenumerata czasopisma dla Komitetu Egzaminacyjnego stawała na posiedzeniu Rady 22 czerwca/8 lipca 1850 r. Wówczas kierownictwo Warszawskiego Okręgu Naukowego wnioskowało o przekazanie do Warszawskiego Urzędu Poczt kwoty 11 rubli srebrnych 87 kopiejek z budżetu państwowego za prenumeratę czasopisma „Joural des Economistes” (ukazywało się w Paryżu w latach 1842-1936). Także i w tym wypadku Rada pozytywnie zaopiniowała wniosek ${ }^{39}$.

Bardzo rzadko zdarzało się, aby Rada negatywnie opiniowała przedkładane wnioski. Do tych wyjątkowych spraw należała rozpatrywana 22 marca/3 kwietnia 1845 r. odmowa spełnienia prośby nauczyciela Instytutu Szlachetnie Urodzonych Panien, Teodozego Sierocińskiego, o wprowadzenie jako podręcznika w szkołach wydanej przez niego Logiki według Johanna Gottfrida Kiesewettera. Uzasadnieniem odmowy było uznanie treści książki za niezgodną z treściami programowymi wykładu logiki w szkołach średnich Królestwa Polskiego ${ }^{40}$.

Wśród spraw, które rozpatrywała Rada Wychowania Publicznego, był także wniosek kierownictwa Warszawskiego Okręgu Naukowego, sformułowany na podstawie pozytywnej opinii dyrektora Kursów Pedagogicznych na temat dopuszczenia do używania w szkołach słowników: francusko-polskiego i polsko-francuskiego Piotra Dahlmanna oraz niemiecko-polskiego i polsko-niemieckiego Augusta Mosbacha. Uznano, że wniosek ten przed zaakceptowaniem przez Radę Wychowania Publicznego powinien być skierowany do akceptacji Namiestnika Królestwa Polskiego, księcia Iwana Paskiewicza, „by łaskawie uznał, czy można je uznać za pożyteczne i dopuścić do użytku uczącej się młodzieży zarówno w rządowych jak i prywatnych szkołach w Królestwie Polskim". Spotkało się to z akceptacją Rady ${ }^{41}$.

Pozostałe kwestie, dotyczące polityki naukowej i oświatowej, które rozpatrywała Rada Wychowania Publicznego, dotyczyły poszczególnych osób. W jednym tylko wypadku, na posiedzeniu 3/15 czerwca 1846 r. była to kwestia stypendium zagra-

kandydatów na profesorów Instytutu Pedagogicznego. Wobec tego, że nie doszło do utworzenia w Warszawie Instytutu Pedagogicznego, Komitet związany został z Kursami Dodatkowymi. Zadaniem Komitetu Egzaminacyjnego było przede wszystkim ocenianie kwalifikacji kandydatów, ubiegających się o posady nauczycielskie w szkołach publicznych. K. Poznański: Oświata i szkolnictwo w Królestwie Polskim 1831-1869. Lata zmagań i nadziei. T. 3 s. 19-22.

\footnotetext{
${ }^{38}$ Rada Wychowania Publicznego w Królestwie Polskim w latach 1845-1850. T. 2, s. 254.

${ }^{39}$ Tamże s. 388.

${ }^{40}$ Rada Wychowania Publicznego w Królestwie Polskim w latach 1845-1850. T. 1, s. 115.

${ }^{41}$ Tamże s. 541.
} 
nicznego Christiana Breslauera ${ }^{42}$. W sprawę tę zaangażowane były najwyższe władze państwowe, bowiem Rada Wychowania Publicznego została poinformowana przez Sekretarza Stanu Rady Administracyjnej, Tomasza Le Bruna, że car na wniosek namiestnika Królestwa Polskiego, ks. I. Paskiewicza, zezwolił Ch. Breslauerowi na wyjazd do Włoch na jeden rok w celu pogłębienia wiedzy w zakresie malarstwa

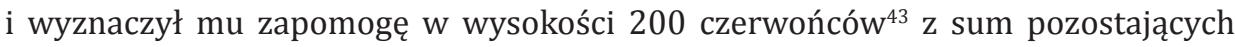
w budżecie Rady Administracyjnej. Rada Wychowania Publicznego równocześnie miała powiadomić Sekretarza Stanu T. Le Bruna, że artysta ten zobowiązał się wobec kierownictwa Warszawskiego Okręgu Naukowego, iż za każdy rok zapomogi odsłuży dwa lata, o ile to będzie korzystne dla władz oświatowych, a także będzie przesyłał raporty o postępie swych prac na terenie Włoch ${ }^{44}$.

W pozostałych wypadkach decyzje Rady Wychowania Publicznego odnosiły się do udzielenia zgody na wyjazdy zagraniczne nauczycieli szkół podległych Warszawskiemu Okręgowi Naukowemu w celu poratowania zdrowia. Po raz pierwszy problemem tym zajmowała się Rada na posiedzeniu 3/15 maja 1845 r., na którym zaakceptowano udzielenie urlopu na wniosek dyrektora Kursów Pedagogicznych ${ }^{45}$ nauczycielowi tych Kursów, Aleksemu Nędzyńskiemu ${ }^{46}$. Dzięki temu mógł on się udać do Karlsbadu i Salzburga do wód mineralnych i przebywać tam przez cały lipiec aż do 28 sierpnia, pobierając swe podstawowe wynagrodzenie w miejscu pracy. Na tym samym posiedzeniu rozpatrywano raport dyrektora II Gimnazjum w Warszawie ${ }^{47}$ o zezwolenie na udzielenie urlopu inspektorowi tego gimnazjum, Mikołajowi Cziczerinowi ${ }^{48}$, który zamierzał

${ }^{42}$ Christian Breslauer (1802-1882), malarz, pejzażysta. Pochodził z niemieckiej rodziny osiadłej w Polsce. Studiował w Berlinie i Dreźnie. Ukończył Akademię Sztuk Pięknych w Düsseldorfie w 1836 r. Do Warszawy powrócił w 1845 r. W latach 1846-1848 wiele podróżował. Na stałe powrócił do kraju w 1848 r. i został nauczycielem rysunku w Szkole Sztuk Pięknych. Po zamknięciu Szkoły został nauczycielem w klasie rysunków. Zmarł w Warszawie 10 sierpnia 1882 r. J. P u ci a ta-Pawło ws ka: Breslauer Chrystjan (1802-1882), PSB, t. II, Kraków 1936, s. 427-428.

${ }^{43} 1$ czerwoniec $=10$ złotych rubli.

${ }^{44}$ Rada Wychowania Publicznego w Królestwie Polskim w latach 1845-1850. T. 1, s. 413.

45 W 1845 r. dyrektorem Kursów był Leopold Sumiński (1798-1862), wyznania rzymskokatolickiego. Do 1832 r. rektor Szkoły Wydziałowej na Muranowie w Warszawie, w 1833-1861 w Radzie Wychowania Publicznego oraz dyrektor Kursów Dodatkowych Pedagogicznych w Warszawie. W 1842--1849 naczelnik Zarządu Warszawskiego Okręgu Naukowego. T. M a n te uffel: Centralne władze oświatowe, s. 98.

${ }^{46}$ Aleksy Nędzyński [Nendzyński] (1804-1846), ur. w powiecie ostrzeszowskim, wyznania rzymskokatolickiego, poch. szlacheckiego, absolwent UW, nauczyciel łaciny, greki i pedagogiki w szkołach średnich Kalisza, Warszawy, Wielunia i ponownie Warszawy. Od 1835 r. wykładał na Kursach Dodatkowych Pedagogicznych w Warszawie. A. Massalski: Słownik biograficzny s. 296.

${ }^{47}$ Dyrektorem II gimnazjum w Warszawie (1835-1848), a następnie Inst. Szlacheckiego (1848-1853) i Szkoły Rabinów był Jan Karwowski (1797-1855), wyznania rzymskokatolickiego, były oficer wojsk Królestwa Polskiego. A. Massalski: Słownik biograficzny s. 194.

${ }^{48}$ Mikołaj Cziczerin (1809-po 1856), wyznania prawosławnego, pochodzenia szlacheckiego. 
udać się do Mariensbadu (Mariańskich Łaźni) w podobnym celu i w podobnym czasie co A. Nędzyński. W wypadku M. Cziczerina Rada Wychowania Publicznego postanowiła dodatkowo wnioskować do Rady Administracyjnej Królestwa Polskiego z prośbą o wyznaczenie mu zapomogi w wysokości 300 rubli srebrnych z sum rezerwowych, pozostających do dyspozycji Rady Administracyjnej ${ }^{49}$.

Ponownie kwestiami urlopów zagranicznych zajmowała się rada 9/21 kwietnia 1845 r., na którym to posiedzeniu pozytywnie zaopiniowano raport dyrektora II Gimnazjum w Warszawie, w sprawie udzielenia nauczycielowi Edwardowi Landie urlopu na 3 miesiące, w którym to czasie zamierzał on udać się do Francji w celach leczniczych. Równocześnie Rada kierowała prośbę do Rady Administracyjnej Królestwa Polskiego o wyznaczenie mu zapomogi w wysokości trzymiesięcznych zarobków, tj. 109 rubli srebrnych 12 1/2 kopiejek $^{50}$.

Wśród spraw załatwianych przez Radę Wychowania Publicznego znajdowały się różnego rodzaju kwestie dotyczące awansów, mianowań, powierzania stanowisk osobom, które były pochodzenia cudzoziemskiego i kształciły się w uniwersytetach lub szkołach zagranicznych. Łącznie w tekście protokołów Rady Wychowania Publicznego występuje ponad 70 nazwisk takich osób. Dotyczyło to na przykład pastorów wyznania ewangelickiego, absolwentów uniwersytetów w Berlinie i Dorpacie, którzy niekiedy pełniąc funkcje nauczycieli religii ewangelickiej w szkołach średnich powoływani byli na opiekunów szkółek ewangelickich i kantoratów w miejscowościach znajdujących się na terenie kierowanej przez nich parafii ${ }^{51}$.W poszczególnych przypadkach informacje zawarte $\mathrm{w}$ obu tomach mogą stanowić uzupełnienia do biogramów niektórych wybitniejszych postaci, takich jak F. Lüdicke, Ch. Breslauer, E. Modl czy L. Otto.

Zaprezentowane powyżej decyzje Rady Wychowania Publicznego podejmowane były tylko w ciągu 5 lat: 1845, 1846, 1848, 1849 i 1850. Tym niemniej wskazują one już wyraźnie na uwarunkowania polityczne ówczesnej sytuacji nauki i oświaty w Królestwie Polskim. Dowodnie na to wskazuje fakt, że w latach 1818-1826, o czym wspomniano wyżej, wysłanych było za granicę około 100 stypendystów, natomiast $\mathrm{w}$ omawianych dwóch tomach materiałów źródłowych obejmujących 5 lat, udało się odnaleźć jednego tylko stypendystę. Uwarunkowania te dokumentuje także fakt ograniczania młodzieży w szkołach średnich kontaktu z podręcznikami obowiązującymi w krajach Europy Zachodniej, czego przykładem jest decyzja odmawiająca dopuszczenia do szkół podręcznika do logiki T. Sierocińskiego.

Pochodził z guberni niżegorodzkiej. Ukończył Szkołę Artyleryjską w 1826 r. Do 1836 r. służył w Wojsku Rosyjskim. W latach 1839-1856 inspektor, następnie dyrektor szkół średnich w Suwałkach oraz w Warszawie. A. M a s s a ls ki: Stownik biograficzny s. 112.

${ }^{49}$ Rada Wychowania Publicznego w Królestwie Polskim w latach 1845-1850. T. 1, s. 149.

${ }^{50}$ Tamże s. 134.

${ }^{51}$ Tamże s. 396-397. 
Z poszczególnych protokołów posiedzeń wynika także proces ograniczonej roli Rady, skoro w dużej mierze zajmowała się w kontaktach z Europą Zachodnią kwestiami głównie zakupu roślin do Ogrodu Botanicznego i eksponatów do Gabinetu Zoologicznego.

\section{BIBLIOGRAFIA}

Bi e li ń s ki J.: Królewski Uniwersytet Warszawski (1816-1831), t. I, Warszawa 1907.

Demidowicz T., Rada Wychowania Publicznego jako "główna zwierzchność szkolna" w Królestwie Polskim 1833-1839/40. „Przegląd Historyczno-Oświatowy” 1992.

Ei s e n bach A.: Emancypacja Żydów na ziemiach polskich 1785-1870 na tle europejskim. Warszawa 1988.

Fe dorowicz Z., Feliksiak S.: 150-lecie Gabinetu Zoologicznego w Warszawie (18181968), „Memorabilia Zoologica” Nowa Seria 1, 2016, s. 15, http://www.muzeum.uw.edu.pl/ uw-w-zrodlach-o-150-leciu-gabinetu-zoologicznego/ [dostęp 6. 08. 2017]

Historia Nauki Polskiej pod red. B. S u c h o d ol s k i e g o , t. III, Wrocław - Gdańsk 1977.

Jakimowicz I, A. Ryszkiewicz: Szkoła Sztuk Pięknych w Warszawie 1844-1866, „Rocznik Warszawski” t. 4: 1963, [druk.] 1964.

Ko s i e k Z.: Oczapowski Michał (1788-1854), PSB, t. 23, s. 522-525.

Ku ch ar z e ws ki J., Epoka paskiewiczowska w Królestwie Polskim. Losy oświaty. Warszawa-Kraków 1914.

Kula E.: Naukowa, literacka i artystyczna twórczość nauczycieli rzq̨dowych męskich szkół średnich Królestwa Polskiego w latach 1833-1862 , Wyd. AŚ, Kielce 2006.

M a n te u f f el T.: Centralne władze oświatowe na terenie b. Królestwa Kongresowego (18171915), Warszawa 1929.

M a s s l s k i A.: Słownik biograficzny. Nauczyciele szkół średnich rządowych męskich w Królestwie Polskim 1833-1862, Warszawa 2007.

Mas s als ki A.: Stypendyści zagraniczni Królestwa Polskiego w czasach Stanisława Staszica. Zarys problemu. „Rozprawy z Dziejów Oświaty” 2006, t. XLV, s. 113-123.

M ią s o J.: Szkoły realne w Królestwie Polskim w okresie międzypowstaniowym, „Rozprawy z Dziejów Oświaty", t. VI, 1963.

Po z n ań s ki K.: Oświata i szkolnictwo w Królestwie Polskim 1831-1869. Lata zmagań i nadziei. t. 1, Przebudowa systemu szkolnictwa i wychowania w Królestwie Polskim w latach 18311839, Warszawa 2001.

Po z n ańs ki K.: Oświata i szkolnictwo w Królestwie Polskim 1831-1869. Lata zmagań i nadziei, t. 3, Polityka oświatowa caratu w latach 1834-1861, Warszawa 2004.

Puciata-Pawłowska J.: Breslauer Chrystjan (1802-1882), PSB, t. II, Kraków 1936, s. 427-428.

Rada Wychowania Publicznego w Królestwie Polskim w latach 1845-1850. Protokoły posiedzeń, t. 1, Lata 1845 i 1846, wybór i oprac. E. Ku la , A. M a s s a l s k i, Łódź-Kielce 2014.

Rada Wychowania Publicznego w Królestwie Polskim w latach 1845-1850. Protokoły posiedzeń, t. II, Lata 1848-1850, wybór i oprac. E. Ku l a, A. M a s s al s k i Łódź - Kielce 2015. 
Российский Государственный Исторический Архив в Санкт Петербурге, фонд 733, опись 77, дела: 167, 198, 243, 271, 301, 302, 336, 357, 387, 406, 421, 440, 463, 486, 504.

S z cze r batow [M.]: Rządy księcia Paskiewicza w Królestwie Polskim (1832-1847), Warszawa 1900.

W i n i r z A.: Szkolnictwo Księstwa Warszawskiego i Królestwa Polskiego (1807-1831), Lublin 2002.

Z a s z to wt L.: Popularyzacja nauki w Królestwie Polskim 1864-1905. Wrocław-七ódź 1989.

Zas z to wt L.: Wstęp, w: Akademie nauk. Uniwersytety. Organizacje nauki. Polsko-rosyjskie relacje $w$ sferze nauki XVIII-XX W., red. L. Z a s z t o wt, Warszawa 2013. 